\title{
STRATEGI PENGEMBANGAN SUMBER DAYA MANUSIA KARYAWAN COMMANDITAIRE VENNOOTSCHAP DALAM MENINGKATKAN EFEKTIVITAS KINERJANYA
}

\author{
Khoirul Umam \\ UIN Sunan Ampel Surabaya \\ kho.um@yahoo.com \\ Akhmad Yunan Atho'illah \\ UIN Sunan Ampel Surabaya \\ yunan.athoillah@uinsby.ac.id
}

\begin{abstract}
Abstrak
Penelitian ini berjudul Strategi Pengembangan Sumber Daya Manusia Karyawan Comanditaire Vennootschap (CV) Dalam Meningkatkan Efektivitas Kinerjanya, pada kasus CV. Barokah Jaya Hikmah, Tambakrejo, Waru, Sidoarjo dan merupakan hasil penelitian kualitatif. Hasil penelitian ini bertujuan untuk mengetahui dan menganalisis strategi pengembangan sumber daya manusia dalam meningkatkan efektivitas kinerja yang dilakukan oleh perusahaan serta peran strategi dalam meningkatkan efektivitas kinerja karyawan di CV. Barokah Jaya Hikmah Sidoarjo. Penelitian ini menggunakan metode deskriftif kualitatif sehingga data yang didapatkan peneliti dari CV. Barokah Jaya Hikmah Sidoarjo. Observasi, dokumentasi dan wawancara mendalam dengan pihak perusahaan CV Barokah Jaya Hikmah. Serta literatur pendukung yang dianggap relevan terhadap penelitian yang diangkat. Hasil penelitian ini menyimpulkan bahwa strategi pengembangan sumber daya manusia dalam meningkatkan efektivitas kinerja karyawan di CV. Barokah Jaya Hikmah Sidoarjo, dengan strategi pendampingan dikatakan efektif dan berjalan sesuai dengan yang di harapkan oleh perusahaan. Dalam hal ini perusahaan mengukur efektifitas dari peran strategi pengembangan sumber daya manusia dalam meningkatkan efektivitas kinerja karyawan dari pendapatan yang mengalami peningkatan. Saran untuk CV. Barokah Jaya Hikmah Sidoarjo, melakukan peninjauan ulang terhadap strategi pengembangan sumber daya manusia yang diterapkan serta melakukan penilaian terhadap karyawan agar efektivitas kinerja sesuai dengan target perusahaan serta melakukan evaluasi kerja.

Kata Kunci: Strategi Pengembangan, Sumber Daya Manusia, Karyawan Commanditaire Vennootschap, Efektivitas Kinerja.
\end{abstract}

\section{PENDAHULUAN}

Di dalam menghadapi persaingan yang semakin ketat pada dunia usaha, Sumber daya manusia (SDM) yang berkualitas menjadi kekuatan bagi perusahaan untuk terus hidup dan mampu bersaing. Maka dari itu pengembangan sumber daya 
manusia harus benar-benar dirancang dengan matang untuk mendapatkan hasil yang memuaskan bagi perusahaan. Perusahaan produksi plastik yang saat ini semakin meningkat persaingan nya Dalam hal ini tentunya perusahaan harus bisa menganalisis kebutuhan yang harus disiapkan untuk mempertahankan perusahaan, baik dari sumber daya manusia atau fasilitas perusahaan.

Di Indonesia sendiri, bisnis dibidang usaha plastik menjadi salah satu bisnis yang lumayan diminati hal ini dilihat dari jumlah usaha yang bergerak dibidang plastik tersebut. Menurut data yang ada di Kementerian Perindustrian Republik Idonesia tercatat sebanyak 973 usaha yang bergerak dibidang plastik dan Jawa Timur ada 299 usaha dan Kota Sidoarjo ada 77 usaha yang bergerak dibidang plastik (www.kemenperin.go.id). Salah satunya CV. Barokah Jaya Hikmah Jl. Perintis III No. 40 RT. 003 RW. 008 Tambakrejo, Waru, Sidoarjo. Perusahaan milik H. Abdul Rohman yang berdiri mulai 1994 dan baru menjadi CV pada 08 Februari 2019. Usaha yang bergerak di bidang produksi pengelolaan plastik ini memiliki 25 karyawan yang rata-rata dimiliki lulusan SMA dan SMK untuk membantu mengelola perusahaan tersebut. Dalam hal ini tentunya perusahaan harus merancang dengan matang proses pengembangan sumber daya manusia yang dimilik untuk meningkatkan kualitas dan hasil kerja yang memuaskan.

Dalam jurnal yang ditulis oleh, Nurul Khurotin dan Tri Wulida Afrianty yang berjudul "Analisis Pelatihan dan Pengembangan Sumber Daya Manusia PT. Beon Intermedia Cabang Malang" mengutip kata "Pelatihan" menurut, Mathis dan Jackson. Pelatihan merupakan proses yang dilalui oleh seorang karyawan agar memperoleh dan meningkatkan kemampuan baru untuk melakukan suatu pekerjaan serta menambah keterampilan secara spesifik (Nurul Khurotin, 2018). Pengembangan karyawan orientasinya tidak hanya diperuntukkan untuk karyawan yang baru, melainkan juga untuk semua karyawan yang berada di perusahaan turut serta mengikuti proses yang diadakan oleh perusahaan gunanya untuk mengenal dan memahami pekerjaan yang akan dihadapi nantinya. Metode pengembangan (development) yang sudah diterapkan oleh perusahaan tentunya perlu diukur baik atau tidak. Metode pengembangan sumber daya manusia (SDM) yang dikatakan baik apabila sudah mencapai sasaran peningkatan kualitas karyawan dalam melaksanakan pekerjaan dan mencapai tujuan yang diinginkan.

Indikator-indikator yang dapat dijadikan ukuran dari pengembangan sumber daya manusia diterapkan sebagai berikut: Prestasi yang dimiliki karyawan, Kedisiplinan karyawan, Tingkat kerusakan hasil produksi, peralatan dan mesinmesin, Tingkat kecelakaan yang terjadi kepada karyawan, Absensi karyawan, Tingkat pemborosan bahan baku, tenaga dan waktu, Tingkat kerjasama karyawan, Tingkat upah insentif karyawan, Prakarsa karyawan, Kepemimpinan dan keputusan manajemen. Indikator ini bisa menjadikan tolak ukur pengembangan karyawan apakah sudah berjalan dengan baik atau tidak, jika metode pengembangan ini tidak tercapai maka perlu adanya evaluasi dalam manajemen sumber daya manusia (MSDM) (Nurul Khurotin, 2018). 
Menurut jurnal yang ditulis oleh, Irma Ernawati, Muhammad Darwis Dan Muh. Nasrullah, yang berjudul "Efektivitas Kinerja Pegawai Pada Kantor Kecamatan Pallangga Kabupaten Gowa" penilaian kerja pada dasarnya merupakan faktor kunci guna untuk mengembangkan suatu organisasi atau perusahaan secara efektif dan efisien, karena adanya kebijakan atau program yang lebih baik atas sumber daya manusia yang ada dalam organisasi (Irma Ernawati, 2017). Proses yang dilakukan oleh manajemen sumber daya manusia mulai dari, pelatihan, pengembangan, keterampilan sampai pemahaman karyawan dan juga penilaian dan evaluasi yang dilakukan oleh manajemen sumber daya manusia (MSDM) tentunya untuk mencapai efektivitas kinerja karyawan dan kelanjutan perusahaan dalam menghadapi persaingan.

Di lanjut oleh Suksono, efektivitas kinerja adalah seberapa besar tingkat kecepatan Out Put yang dihasilkan kepada perusahaan, In Put dapat berwujud yaitu pencapaian skill yang dimiliki oleh sumber daya manusia secara personalia, makin sesuai Out Put dan In Put yang dihasilkan maka bisa dikatakan efektif (Sigit Sutikno, 2018). Pada dasarnya efektifitas kinerja karyawan bertujuan untuk mencapai target yang sudah ditentukan oleh perusahaan, maka dari itu adanya penekanan atau target kepada karyawan untuk menyelesaikan pekerjaannya, gunanya untuk, efisiensi waktu, biaya dan tenaga mutu. Efektivitas kinerja bisa tercapai juga perlunya dorongan yang kuat atau motivasi yang diberikan atasan kepada bawahannya, sehingga karyawan juga termotivasi dalam melaksanakan pekerjaannya.

Perseroan Terbatas (PT). PT adalah badan usaha yang modalnya terbagi atas sero (saham), pergerakan PT pun lebih luas dibandingkan lainnya, tergantung modal yang dimiliki oleh pemegang saham saja untuk mengembangkan usaha tersebut. Commanditaire Vennootschap (CV). CV adalah badan usaha yang lingkupnya lebih kecil, beda dengan PT yang memang ruang geraknya lebih luas. Commanditaire Vennootschap (CV), merupakan bentuk usaha yang dipilih oleh beberapa orang yang ingin memiliki kegiatan usaha namun dengan modal yang minim. Firma (FA). FA. Adalah badan usaha yang hanya didirikan oleh 2 orang atau lebih, modal dalam kegiatan usaha ini berasal dari anggota pendiri. Jenis FA yaitu, dagang dan non dagang. Usaha Dagang (UD). UD adalah kegiatan usaha yang bisa dilakukan oleh perorangan, bentuk kegiatan usaha ini adalah kegiatan jual beli barang atau jasa (www.pinterpandai.com).

Umumnya persoalah yang telah tampak dalam beberapa penelitian mengenai hal ini adalah menurunnya semangat kerja karyawan, kurangnya peningkatan sumber daya manusia, tingkat keahlian kerja karyawan, proses pekerjaan produksi yang tidak stabil. Kebanyakan para peneliti juga banyak mengkonsetrasikan obyek penelitianya pada level badan usaha yang yang memiliki modal menengah keatas sebagaimana Firma dan Perseroan, dengan cakupan usaha yang luas, namun jarang sekali penelitian yang mengali lebih mendalam tetang persoalan pengembangan karyawan dalam raung lingkup Commanditaire 
Vennootschap. Peneitian ini sesungguhnya hadir untuk memberikan beberapa sumbangsih terkait pengembangan karwayan pada level Commanditaire Vennootschap, untuk menjawab dua rumusan masalah, yaitu Bagaimana strategi pengembangan sumber daya manusia yang diterapkan level Commanditaire Vennootschap? Bagaimana peran strategi pengembangan sumber daya manusia dalam meningkatkan efektivitas kinerja karyawan level Commanditaire Vennootschap?.

Penelitian deskriptif kualitatif disebut, juga penelitian naturalistik karena dilakukan secara natural setting, post positivistic, artistik, interpretative (Nurlina T. Muhyiddin, 2017). dilaksanakan pada CV. Barokah Jaya Hikmah Jl. Perintis III No. 40 RT. 003 RW. 008 Tambakrejo, Waru, Sidoarjo. Peneltian ini dilakukan pada bulan januari sampai maret 2020. Guna mendapatkan data atau informasi dalam penelitian kualitatif ini, peneliti menggunakan teknik Observasi, Wawancara, Dokumentasi. Data yang di peroleh kemudian dikelola melalui editing, organizing, kesimpulan hasil (Arikunto, 1996). Untuk kemudian dianalisis secara akurat berdasarkan fakta atau fenomena yang terjadi di lapangan menggunakan metode kualitatif deskriptif. Proses olahan data deskriptif kualitatif dimulai dari sumber data yang dimiliki oleh peneliti kemudian akan ditinjau dengan berdasarkan dengan teori yang digunakan sebagai pisau analisa dan hasil data di lapangan tersebut berdasarkan pengumpulan data dan pengelilaan data secara sistematis (Moh. Nazir, 2005).

Berdasarkan rumusan masalah di atas, maka tujuan dari peneliti yang diharapkan yaitu sebagai berikut: Untuk menganalisis Bagaimana strategi pengembangan sumber daya manusia yang diterapkan oleh CV. Barokah Jaya Hikmah, Waru, Sidoarjo dan Untuk menganalisis peran strategi pengembangan sumber daya manusia dalam meningkatkan Efektivitas Kinerja Karyawan CV. Barokah Jaya Hikmah, Waru, Sidoarjo.

\section{LANDASAN TEORI}

Ada tiga landasan teori yang digunakan dalam penelitian ini yang petama adalah teori stategi pengembangan SDM, Teori Efektiftas, dan Teori Kinerja. Teori yang menjadi dasar dalam penelitian ini yaitu teori pengembangan sumber daya manusia. Pengembangan sumber daya manusia adalah suatu usaha dengan tujuan meningkatkan skill karyawan melalui pendidikan, pelatihan serta pengembangan akhir guna menjalankan tugas sebagai karyawan dan memiliki siklus jangka panjang (Robert, 2002). Adapun Strategi berasal dari bahasa yunani yaitu kata "Strategas" artinya "Generalship" atau pekerjaan yang biasanya dilakukan oleh jenderal untuk menyusun rencana memenangkan perang. Konsep ini relevan pada zaman dahulu dimana jenderal dibutuhkan untuk memimpin angkatan perang. Secara umum strategi adalah suatu proses yang menentukan rencana pemimpin yang berada dalam organisasi yang fokusnya pada jangka panjang organisasi, serta bagaimana penyusunan, rencana agar mencapai tujuan (Aruperes Dinny M., 2018). 
Menurut Gluueck dan Jauch strategi adalah program yang sangat luas dalam mencapai tujuan yang sudah ada dalam organisasi/perusahaan, kata "program" dalam definisi tersebut mencerminkan peran yang aktif dan rasional dalam merumuskan strategi organisasi yang dilakukan oleh manajer untuk menggerakkan sumber daya yang dimiliki ke arah tujuan organisasi. Di lanjut oleh Abdul Basit, mengatakan strategi adalah suatu pendekatan yang dilakukan secara keseluruhan dan berkaitan dengan implementasi, ide, atau gagasan, perencanaan dan pelaksanaan sebuah proses kegiatan dalam kurun waktu tertentu.

Menurut Robert M. Grant, Strategi dalam manajemen ada tiga peran penting yaitu, strategi sebagai pengambilan keputusan, strategi sebagai sarana koordinasi dan komunikasi dan strategi sebagai target konsep strategi yang akan dipadukan dengan visi dan misi untuk menentukan tujuan perusahaan jangka panjang. Strategi merupakan hal yang penting untuk mencapai tujuan yang sudah ada dalam organisasi, tujuan akan dicapai jika keputusan, perencanaan yang sudah ditetapkan oleh perusahaan dilandasi dengan pertimbangan yang matang (Aruperes Dinny M., 2018:24).

Menurut jurnal yang ditulis oleh, Paulina yang berjudul Efektivitas Kinerja Karyawan Pada PT. PLN (Persero) Distribusi Jawa Timur Area Malang Rayon Dinoyo Untuk Mewujudkan Pelayanan Prima, mengutip kata "Efektivitas" menurut Handoko. Efektivitas merupakan kemampuan untuk memilih tujuan yang tepat serta peralatan yang tepat dalam rangka untuk mencapai tujuan yang sudah ditetapkan dengan pekerjaan yang efektif. Di lanjut oleh Robbins. Efektivitas diartikan sebagai proses tingkatan dalam mencapai tujuan yang ada di dalam perusahaan baik pencapaian secara jangka pendek dan jangka panjang dan kemampuan yang dimiliki. Diteruskan oleh Rahadhitya \& Darsono. Mengatakan efektivitas secara umum menunjukkan seberapa jauh target yang sudah tercapai yang sudah ditentukan oleh organisasi/perusahaan (Paulina, 2016).

Seperti yang dipaparkan diatas dapat diartikan bahwa, Efektivitas adalah suatu keberhasilan dalam pencapaian yang dilakukan oleh kelompok atau individu dalam melaksanakan pekerjaan yang dapat dilihat dari hasil, kualitas, waktu pekerjaan, dan hasil yang diperoleh. Faktor-Faktor Efektivitas Menurut Zulyanti, Resi Yudhaningsih. Mengatakan faktor-faktor yang mempengaruhi efektivitas kinerja adalah sebagai berikut: Karakteristik organisasi, Karakteristik lingkungan, Karakteristik pekerja, Kebijakan dan praktek manajemen. Di lanjut oleh The Iang Gie. Mengatakan bahwa faktor-faktor yang mempengaruhi efektivitas dan efisiensi adalah sebagai berikut: Motivasi, Kemampuan, Suasana kerja, Lingkungan kerja, Fasilitas pekerja, Produktivitas (Juemi, 2013).

Seperti yang sudah dipaparkan diatas dapat disimpulkan bahwasanya faktor-faktor yang mempengaruhi efektivitas kinerja karyawan adalah kemampuan sumber daya manusia yang dimiliki serta fasilitas yang mendukung untuk pelaksanaan kerja karyawan. Dalam penelitian "Efektivitas Kerja Pegawai Di Dinas Lalu Lintas Angkutan Jalan Kota Surakarta" dinyatakan bahwa indikator dari 
efektivitas kinerja bisa dikatakan efektif ketika memenuhi 6 (enam) indikator berikut: Hasil kerja, Jumlah pegawai, Pelaksanaan pekerjaan atau waktu, Biaya, Kepuasan, Kepuasan dari pengguna. Efektivitas pekerjaan yang dilihat dari penilaian pengguna atau konsumen dapat dilihat dari, loyalitas, dan kerja sama yang dilakukan dengan perusahaan. Pekerjaan yang memuaskan konsumen maka perusahaan juga jarang mendapatkan komplain dari konsumen, karena kepuasan mereka sudah terpenuhi dari perusahaan.

Menurut jurnal yang ditulis oleh, H. Asep Qustolani yang berjudul, pengaruh kepuasan kerja, keadilan prosedural dan kompensasi terhadap kinerja karyawan (Studi Kasus Pada Industri Rotan Kec. Leuwimunding Majalangka), mengutip kata "Kinerja", Menurut mangkunegara. mengatakan kinerja karyawan merupakan suatu pencapaian yang dilakukan dengan kualitas dan kuantitas yang dilakukan secara maksimal sesuai dengan tanggung jawab yang telah diberikan kepada karyawan (Qustolani, 2017). Diteruskan oleh, H. Malayu. Mengatakan kinerja pegawai merupakan hasil kinerja yang dicapai orang dalam melaksanakan tugas-tugas yang diberikan kepada pegawai berdasarkan pengetahuan, kesungguhan serta waktu pengerjaan. Diteruskan oleh Arif Yusuf Hambali. Mengatakan kinerja merupakan hail dari pekerjaan yang mempunyai hubungan dengan tujuan perusahaan, strategi, kepuasan konsumen, dan memberikan kontribusi pada ekonomi (Eri Bukhari, 2018).

Berdasarkan pemaparan diatas, kinerja merupakan suatu hasil yang dicapai oleh karyawan baik secara individu atau kelompok, kinerja merupakan jawaban dari keberhasilan perusahaan dalam mencapai tujuan atau visi dan misi yang sudah ditetapkan oleh manajemen perusahaan, kinerja juga menjadi tolak ukur masa depan perusahaan dan karyawan.

\section{HASIL DAN PEMBAHASAN}

Penelitian ini menghasilkan banyak informasi yang didapatkan tentang strategi pengembangan sumber daya manusia dalam meningkatkan efektivitas kinerja karyawan di CV. Barokah Jaya Hikmah. sebuah Commanditaire Vennootschap (CV) mendapatkan pengakuan dari pemerintah dengan surat yang dikeluarkan pada, tanggal 08 februari 2019 telah resmi terdaftar di notaris dengan nomer induk berusaha (NIB): 9120006290381. NPWP: 90.292.984.3.643.000. Bentuk usaha plastik dengan nama CV Barokah Jaya Hikmah, dengan alamat Jl. Perintis III No. 40 RT. 003 RW. 008 Tambakrejo, Waru, Sidoarjo. Dengan VISI : Menjadi perusahaan yang berkesinambungan dan stabil dengan mengedepankan kualitas produk dengan service yang baik dan harga yang kompetitif. Dan MISI : Pertama; Melakukan internal effort dengan pengembangan dan perbaikan di tiap aktivitas harian. Kedua; Berani bersaing dengan kompetitor agar mampu menjadi yang terbaik. Ketiga; Meningkatkan kualitas barang yang dihasilkan secara maksimal. 
CV ini berkembang dengan memiliki SDM yang menempati beberapa posisi didalamnya mulai dari: Komisaris, Direktur utama, Sekretaris utama, Direktur keuangan, Manager personal, Manager pemasaran, Manager SDM, Manager Pabrik, Manager Administrasi Gudang, dan para karyawan lainnya. AdapunTujuan berdirinya CV Barokah Jaya Hikmah secara khusus yaitu, untuk menghidupi keluarga dan membantu saudara-saudara untuk mendapatkan pekerjaan. Tujuan secara umum yaitu, bisa membantu masyarakat di sekitar untuk mendapatkan pekerjaan dan membantu perekonomian masyarakat dengan adanya perusahaan.

\section{Strategi pengembangan sumber daya manusia yang diterapkan oleh CV. Barokah Jaya Hikmah, Waru, Sidoarjo.}

Pengembangan sumber daya manusia yang dimaksud peneliti meliputi strategi pengembangan sumber daya manusia yang ada di CV Barokah Jaya Hikmah Sidoarjo. Informasi yang diambil oleh peneliti mulai dari, komisaris, direktur dan manajer yang ada di perusahaan. Menurut informasi yang didapatkan oleh peneliti dari Hj. Abd. Rohman komisaris CV. Barokah Jaya Hikmah: "Pengembangan sumber daya manusia yang kami lakukan masih menggunakan pendampingan kepada karyawan baru atau lama karena masih belum ada pelatihan yang dilakukan secara formal yang dilakukan oleh perusahaan" (Abd. Rohman. April 2020).

Selain itu juga menurut bapak faisol sebagai direktur utama, menegaskan: "Pengembangan sumber daya manusia yang dilakukan menggunakan pendampingan dalam melaksanakan pekerjaan yang dilakukan agar mempermudah karyawan dalam melaksanakan pekerjaan yang sudah ditentukan dari perusahaan" (Faisol, April 2020).

Selain itu juga, diperkuat dengan oleh Fatur Rohman Manajer Sumber Daya Manusia menegaskan sebagai berikut: "Pendampingan dilakukan kepada karyawan lebih efektif dan tidak memakan biaya dibandingkan melakukan pelatihan formal, karena karyawan didampingi sambil melakukan pekerjaan jadinya karyawan lebih hati-hati dalam melaksanakan pekerjaan" (Fatur, April 2020)

Menurut ibu Dewi Sukma bagian manajer pemasaran menegaskan sebagai berikut: "Proses pengembangan sumber daya manusia dilakukan dengan cara pendampingan lebih efektif karena kita juga bisa langsung mengarahkan sambil melakukan kontrol kepada karyawan dalam melakukan pekerjaan dan juga mereka lebih cepat memahami pekerjaanya dibandingkan masih harus mengikuti pelatihan yang memerlukan waktu yang lumayan lama, lebih baik waktu itu digunakan untuk bekerja" (Dewi, April 2020).

Pernyataan diatas menunjukkan bahwa proses peningkatan sumber daya manusia yang dilakukan oleh perusahaan CV Barokah Jaya Hikmah Sidoarjo dilakukan dengan pendekatan atau pendampingan kepada karyawan yang ada sehingga ikatan emosional dalam bekerja menjadi lebih kuat dan rasa kekeluargaan 
dalam perusahaan akan terasa, sehingga untuk mencapai target perusahaan bisa dilakukan dengan lancar.

Selain itu ibu Siti Nur Aida Bagian Admin Gudang juga menyampaikan: "pengembangan dilakukan dengan cara pendampingan yang dilakukan oleh bidang yang ada di CV Barokah Jaya Hikmah sudah dikatakan memuaskan secara hasil kerja, asalkan kontrol kepada mereka juga dilakukan dengan maksimal" (Siti, April 2020)

Selain itu bapak Bapak Bambang Bagian Manajer Personal menyampaikan sebagai berikut: "proses pendampingan yang dilakukan lebih dirasa efektif karena selain melakukan pendampingan pada karyawan kita juga lebih akrab dan menjalin ikatan emosional pada karyawan" (Bambang, April 2020).

Menurut Bapak Ubaidillah Manajer Pabrik juga menyampaikan sebagai berikut: "iya proses peningkatan karyawan yang lebih bagus itu dilakukan pendampingan karena mereka bekerja sambil di dampingi, kalau karyawan yang lama kadang ada juga yang ikut seminar tapi itu tidak diharuskan oleh perusahaan yang diharuskan itu pendampingan untuk karyawan yang masih belum paham sepenuhnya dengan pekerjaannya" (Ubaidillah, April 2020).

Berdasarkan informasi yang didapatkan dari 7 orang di perusahaan mulai dari komisaris sampai manajer jawabannya sama, bahwa karyawan CV. Barokah Jaya Hikmah Sidoarjo dalam pengembangan sumber daya manusia memiliki budaya sendiri dengan melakukan pendampingan kepada karyawan untuk mengembangkan karyawan yang dimiliki. Hal ini bertujuan agar pengeluaran pembiayaan yang dikeluarkan lebih minim selain itu mereka merasa strategi yang dilakukan lebih efektif karena karyawan bisa bekerja sambil diarahkan oleh masing-masing bidang yang dibutuhkan.

\section{Peran strategi pengembangan sumber daya manusia dalam meningkatkan efektivitas kinerja karyawan CV. Barokah Jaya Hikmah Sidoarjo.}

Peran yang dimaksud peneliti disini adalah hal-hal yang mempengaruhi peningkatan efektivitas kinerja karyawan, mulai dari kualitas sampai hasil kerja. Informasi yang telah didapat dari wawancara kepada pihak perusahaan mulai dari, komisaris perusahaan sampai manajer yang ada di CV. Barokah Jaya Hikmah Sidoarjo. Yaitu hasil kerja yaitu, secara kualitas yang dimaksud peneliti adalah tentang bagaimana hasil pekerjaan yang sudah dijalankan oleh karyawan CV. Barokah Jaya Hikmah Sidoarjo.

Menurut informasi yang diterima oleh peneliti dari bapak faisol sebagai direktur CV. Barokah Jaya Hikmah Sidoarjo, menggunakan wawancara online menyampaikan sebagai berikut: "adanya peran pendampingan membuat pekerjaan yang mereka jalankan dilakukan dengan hati, hasilnya pun sudah baik meskipun nanti akan dipilih kembali di sesuaikan dengan kualitas barang yang dihasilkan" (Faisol, April 2020).

Selain itu informasi dari Bapak Bambang Bagian Manajer Personal menyampaikan sebagai berikut: "peran strategi yang dijalankan dengan 
pendampingan dinilai sudah bagus diihat dari pendapatan perusahaan dan hasil kerja yang dilakukan dengan maksimal oleh karyawan. pekerjaannya pun dilakukan sesuai dengan target atau kebutuhan perusahaan itu sudah di katakan efektif", (Bambang, April 2020). Menurut Ibu dewi sukma bagian pemasaran menyampaikan sebagai berikut: "ketika mereka melakukan pekerjaan dengan baik dan hasilnya sesuai dengan harapan dan bertanggung jawab dalam pekerjaan. Peran dari proses pendampingan yang dilakukan itu sangat dirasakan dari hasil yang didapatkan"(Dewi, April 2020).

Berdasarkan informasi yang didapatkan dari karyawan CV Barokah Jaya Hikmah Sidoarjo, peran strategi yang dilakukan oleh perusahaan sangat dirasakan oleh karyawan bahkan dari pendapatan perusahaan per bulannya, pekerjaan yang dilakukan juga sesuai dengan harapan dari CV Barkah Jaya Hikmah Sidoarjo.

Selain itu informasi yang didapat dari Fatur Rohman Manajer Sumber Daya Manusia sebagai berikut: "alhamdulillah, pendapatan perusahaan meningkat, pekerjaan dilakukan terhitung cepat tidak membuang waktu dan menjalankan pekerjaan sesuai dengan aturan yang ada di perusahaan”. Kemudian menurut bapak ubaidillah sebagai manager yang berada di bagian pabrik menyampaikan sebagai berikut: "tentunya sangat berpengaruh karena ketika rapat akhir bulan saya lihat perusahaan selalu meningkat jadi kalau bukan dari peran strategi yang dijalankan perusahaan dari apa lagi. Peningkatan efektivitas kinerja karyawan juga baik karena hasil kerja yang diberikan sudah dinilai sudah maksimal dan juga controlling jangan sampai lalai" (Fatur, April 2020).

Informasi yang di dapat peneliti dari Ibu Siti Nur Aida manager administrasi gudang sebagai berikut: "dengan adanya proses pendampingan karyawan yang baru atau yang lama tidak merasa canggung dalam menjalankan pekerjaannya. Tanggap dan cepat dalam menjalankan pekerjaan apalagi dibagikan administrasi yang memang menjadi kebutuhan dari perusahaan”' (Siti, April 2020).

Dari hasil wawancara yang dilakukan kepada 7 orang di perusahaan ratarata jawabannya sama bahwa, peran strategi yang diterapkan oleh CV. Barokah Jaya Hikmah Sidoarjo dalam meningkatkan efektivitas kinerja karyawan dikatakan efektif. Hal ini dilihat dari pendapatan perusahaan setiap bulannya dan hasil kerja karyawan. Informasi yang di dapatkan oleh peneliti dari ibu HJ. Huzaimah selaku bagian keuangan CV. Barokah Jaya Hikmah Sidoarja. Di bawah ini: 
Tabel Pendapatan Bersih .4.2

CV. Barokah Jaya Hikmah, Sidoarjo. Januari-Maret 2020

\begin{tabular}{|l|l|l|l|l|l|}
\hline \multicolumn{2}{|c|}{ Januari } & \multicolumn{2}{c|}{ Februari } & \multicolumn{2}{c|}{ Maret } \\
\hline Produksi & Pendapatan & Produksi & Pendapatan & Produksi & Pendapatan \\
\hline 30 Ton & Rp. & 31 Ton & Rp. & 33 Ton & Rp. \\
& 263.000 .000$, & & 272.000 .000$, & & 296.000 .000$, \\
\hline
\end{tabular}

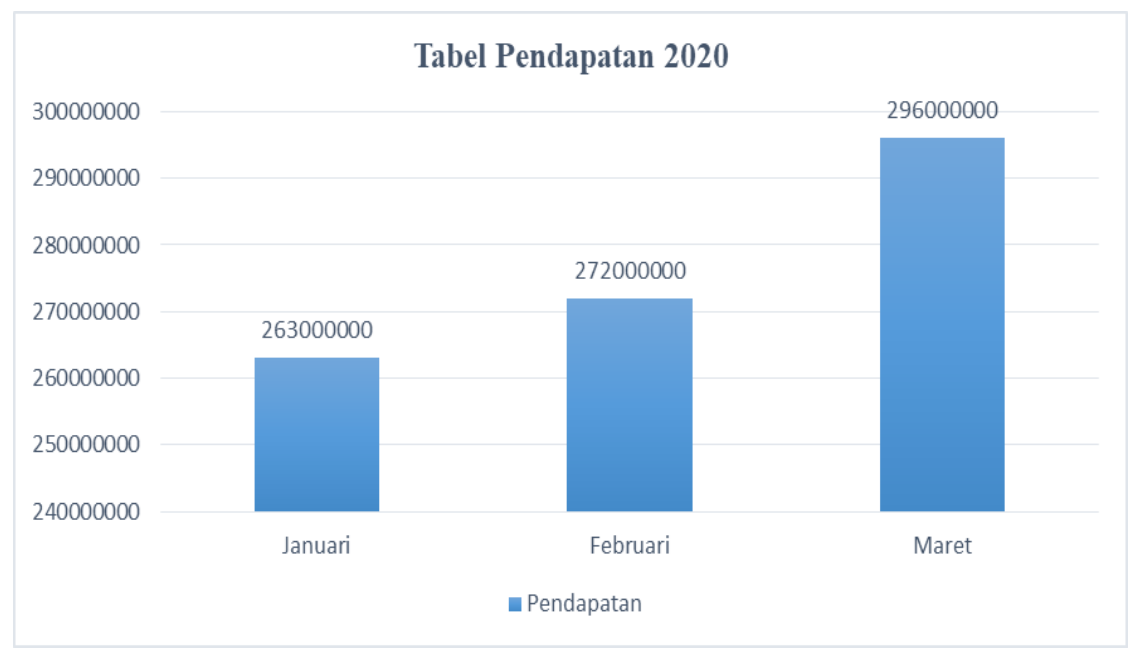

Dari tabel diatas dapat dilihat bahwa pendapatan yang diperoleh perusahaan CV. Barokah Jaya Hikmah, Sidoarjo selama tiga bulan mulai dari januari-maret 2020 mengalami peningkatan pendapatan yang signifikan. Hal ini menunjukkan bahwa penilaian perusahaan terhadap kinerja karyawan dianggap efektif. Maka dari itu kesimpulan dari hasil wawancara dan informasi yang didapatkan bahwa, penilaian yang dilakukan perusahaan dalam penerapan strategi pengembangan sumber daya manusia dengan menggunakan pendampingan dikatakan efektif. Akan tetapi perusahaan CV. Barokah Jaya Hikmah Sidoarjo, seharusnya tidak hanya berpatokan kepada pendapatan perushaan melainkan juga memperhatikan aspek pekerjaan yang lainya, mulai dari kecepatan, hasil kerja dan kepuasan, agar target perusahaan bisa tercapai secara jangka panjang. 
Berdasarkan dari data hasil wawancara yang telah dijalankan oleh peneliti, maka dapat dilakukan sebuah analisis dan pembahasan tentang, strategi pengembangan sumber daya manusia dalam meningkatkan efektivitas kinerja karyawan CV. Barokah Jaya Hikmah Sidoarjo.

\section{Analisis strategi pengembangan sumber daya manusia yang diterapkan oleh CV. Barokah Jaya Hikmah Sidoarjo.}

Dari hasil wawancara online yang peneliti lakukan sebagaimana yang telah dipaparkan diatas sesuai dengan fakta yang ada di lapangan dapat diketahui bahwa strategi pengembangan sumber daya manusia yang dilakukan oleh CV Barokah Jaya Hikmah Sidoarjo, menunjukkan bahwa strategi dalam pengembangan sumber daya manusia yang dilakukan adalah pendekatan atau pendampingan. Hal ini dikatakan efektif serta menghemat pendanaan yang dikeluarkan oleh perusahaan.

Menurut Robert M. Grant, Strategi dalam manajemen ada tiga peran penting yaitu, strategi sebagai pengambilan keputusan, strategi sebagai sarana koordinasi dan komunikasi dan strategi sebagai target konsep strategi yang akan dipadukan dengan visi dan misi untuk menentukan tujuan perusahaan jangka panjang. Maka dari itu pengambilan keputusan menjadi hal terpenting dalam perusahaan karena ketika perusahaan salam dalam pengambilan keputusan maka akan berdampak terhadap kelanjutan perusahaan. Pengambilan keputusan yang dilakukan di CV. Barokah Jaya Hikmah Sidoarjo tidak cukup sulit karena proses pengambilan keputusan yang di pimpin oleh komisaris perusahaan sendiri dan perwakilan dari setiap bagian yang ada di perusahaan, seperti pengambilan keputusan dalam proses pengembangan sumber daya manusia yang dilakukan oleh perusahaan yang sampai saat ini masih tetap dijalankan.

Proses pengembangan sumber daya manusia yang dilakukan dengan model pendampingan dirasa lebih efektif oleh perusahaan CV. Barokah Jaya Hikmah Sidoarjo. Efektif yang dimaksud perusahaan disini adalah perusahaan lebih sedikit pengeluaran keuangan perusahaan dari pada dianggarkan untuk pelatihan, perusahaan lebih memilih keuangan untuk kebutuhan perusahaan yang lainnya. Selain itu juga hasil dari strategi pendampingan yang dilakukan oleh perusahaan dirasa sudah memuaskan dalam hasil kerja yang dihasilkan oleh karyawan, karena perusahaan selalu mengalami peningkatan dalam penghasilan yang didapatkan per bulannya maka dari itu perusahaan beranggapan bahwa strategi yang dilakukan dengan model pendampingan itu dirasa lebih efektif.

Secara ilmu manajemen sumber daya manusia dalam proses pengembangan sumber daya manusia di sebuah perusahaan tentunya harus mempunyai tahapan sebagai berikut: recruitment, development, training, compensation, integration, maintenance, separation, planning, organizing, directing dan controlling. Tahapan seperti ini yang biasanya perusahaan lain menjalankan pengembangan sumber daya manusia yang dilakukan, selain itu juga untuk lebih meningkatkan skill karyawan perusahaan membuat sebuah pelatihan, seminar atau workshop agar karyawan yang dimiliki dapat melaksanakan pekerjaan secara maksimal. Namun memang tidak 
semua perusahaan melakukan semua tahapan tersebut, sama halnya dengan perusahaan CV. Barokah Jaya Hikmah Sidoarjo yang hanya melakukan beberapa tahapan saja untuk menjalankan perusahaan yang dikelolanya, strategi yang dijalankan dengan model pendampingan atau arahan yang mereka ketahui dan dijalankan secara tekun dan Istiqamah, sehingga hasilnya pun memuaskan dan sesuai dengan yang perusahaan harapkan.

Selain proses pengembangan sumber daya manusia yang dilakukan dengan model pendampingan, perusahaan seharusnya juga harus mempunyai rancangan ke depan untuk mengembangkan sumber daya manusia yang dimiliki agar pengembangan sumber daya manusia yang dilakukan oleh perusahaan lebih maksimal, sejauh ini perusahaan CV. Barokah Jaya Hikmah Sidoarjo hanya berpatokan kepada pendapatan yang diperoleh per bulannya ketika pendapatan meningkat maka proses pekerjaan yang dilakukan oleh karyawan dikatakan sudah efektif dan sesuai dengan harapan perusahaan dalam mencapai target yang ada. sebenarnya tidak hanya dilihat dari hasil kerja dalam proses pendampingan juga memunculkan rasa tanggung jawab yang besar kepada seluruh karyawan yang ada di perusahaan dalam melaksanakan pekerjaannya.

Dari hasil analisis dan pembahasan peneliti menunjukkan bahwa pengembangan sumber daya manusia dengan strategi pendampingan sudah dikatakan efektif dari hasil kerja yang diperoleh oleh karyawan CV. Barokah Jaya Hikmah Sidoarjo.

\section{Analisis Peran strategi pengembangan sumber daya manusia dalam meningkatkan efektivitas kinerja karyawan CV. Barokah Jaya Hikmah Sidoarjo.}

Peran strategi pengembangan sumber daya manusia yang di terapkan oleh CV. Barokah Jaya Hikmah Sidoarjo dalam mengikatkan efektivitas kinerja karyawan yaitu dengan strategi pendampingan kepada karyawan baru atau yang lama sekalipun sudah dikatakan efektif. Hal ini dapat dilihat dari hasil kerja yang diberikan karyawan kepada perusahaan baik hasil secara kualitas dan hasil kerja. Maka dari itu peran strategi peningkatan efektivitas kinerja karyawan yang dilakukan secara pendampingan dianggap sudah efektif. Selain itu efektivitas sendiri menurut Darsono mengatakan efektivitas secara umum menunjukkan seberapa jauh target yang sudah tercapai yang sudah ditentukan oleh organisasi/perusahaan.

Maka dari itu peran strategi dalam perusahaan menjadi hal yang terpenting untuk menentukan masa depan perusahaan sebab perusahaan harus mampu mencapai target yang sudah ditentukan oleh perusahaan, sama halnya dengan perusahaan CV. Barokah Jaya Hikmah Sidoarjo langkah yang mereka gunakan dalam pencapaian target produk yang dihasilkan oleh perusahaan dari sistem kinerja karyawan yang mereka miliki harus bisa menjalankan pekerjaan secara maksimal. 
Perusahaan CV. Barokah Jaya Hikmah Sidoarjo dalam meningkatkan efektivitas kinerja karyawannya hanya mengukur dari pendapatan yang diperoleh perusahaan per bulannya. Efektivitas kinerja karyawan sebenarnya harus dilihat dari penilaian sebagai berikut: hasil kerja secara kualitas dan kuantitas, jumlah pegawai, waktu, biaya dan kepuasan kerja. Hal ini seharusnya menjadi tolak ukur dalam peningkatan efektivitas kinerja karyawan yang ada di CV Barokah Jaya Hikmah Sidoarjo, tidak hanya dilihat dari pendapatan perbualan yang didapatkan oleh perusahaan.

Maka dari itu peran strategi dalam meningkatkan efektivitas kinerja karyawan tidak hanya dilakukan dengan cara pendampingan melainkan juga harus memiliki rancangan yang baik untuk perusahaan ke depannya. Dari hasil wawancara online yang dilakukan oleh peneliti di perusahaan, semua responden menjawab bahwa selama ini perusahaan CV. Barokah Jaya Hikmah Sidoarjo hanya melakukan pendampingan kepada karyawan dalam meningkatkan efektivitas kinerja karyawan.

Efektivitas kinerja karyawan yang dianggap oleh perusahaan, ketika pekerjaan yang dilakukan oleh para karyawan sudah dijalankan dengan baik serta bertanggung jawab dalam pekerjaanya. Hal ini tentunya masih kurang dilihat dari besarnya perusahaan CV. Barokah Jaya Hikmah Sidoarjo, seharusnya perusahaan mengukur penerapan strategi pengembangan sumber daya manusia yang dimilikinya dengan melihat hasil kerja yang dihasilkan oleh karyawan.

Hasil kerja yang dimaksud peneliti adalah seberapa banyak barang yang dihasilkan oleh karyawan setiap harinya dengan jumlah karyawan yang dimiliki oleh perusahaan. Disini perusahaan hanya melihat pendapatan per bulan yang diperoleh perusahaan, seharusnya ada target yang diberikan kepada karyawan dalam menjalankan pekerjaan yang diberikan perusahaan kepada mereka.

Selain itu proses pengerjaan atau waktu. Pekerjaan yang dilakukan oleh karyawan masih belum ada target waktu yang kongkrit dari perusahaan, hanya saja perusahaan meminta kepada karyawan asalkan target dan kebutuhan perusahaan terpenuhi. Hal ini menyebabkan terkadang ada penumpukan produk yang dihasilkan karena kebutuhan yang dimaksud perusahaan tidak dimengerti oleh karyawan mereka hanya bekerja sesuai dengan pekerjaan yang diberikan kepada mereka.

Kepuasan kerja, dari hasil wawancara online kepada manajer yang ada di CV. Barokah Jaya Hikmah Sidoarjo dari hasil kepuasan kerja. Mereka menilai pekerjaan yang dihasilkan oleh karyawan sudah baik dan maksimal, karena pendapatan perusahaan meningkat per bulannya. Hal inilah yang menjadikan 
penilaian perusahaan kepada karyawan bahwa karyawan yang ada di perusahaan melaksanakan pekerjaan secara maksimal.

Dalam penerapan strategi peningkatan efektivitas kinerja karyawan seharusnya perusahaan CV. Barokah Jaya Hikmah Sidoarjo, melakukan perencanaan yang matang terlebih dahulu, meskipun secara pendapatan perusahaan per bulannya meningkat belum bisa memastikan bahwa peningkatan secara individu karyawan yang dimiliki benar tercapai oleh perusahaan.

\section{KESIMPULAN}

Berdasarkan hasil penelitian yang dilakukan oleh penulis tentang strategi pengembangan sumber daya manusia dalam meningkatkan efektivitas kinerja karyawan di CV. Barokah Jaya Hikmah Sidoarjo.

Pertama; Strategi pengembangan sumber daya manusia dalam meningkatkan efektivitas kinerja karyawan dengan strategi pendampingan dinilai efektif oleh perusahaan CV. Barokah Jaya Hikmah Sidoarjo. Hal ini dilihat dari pendapatan perusahaan yang mengalami peningkatan per bulannya, selain itu juga perusahaan menganggap strategi pendampingan yang dilakukan lebih meminimalisir pengeluaran keuangan perusahaan, artinya perusahaan lebih memprioritaskan kebutuhan perusahaan yang lainnya dari pada keuangan perusahaan dikeluarkan untuk pelatihan karyawan secara formal. Karyawan yang bekerja di perusahaan CV. Barokah Jaya Hikmah Sidoarjo, juga merasakan proses pendampingan yang diterapkan oleh perusahaan membuat mereka menjadi lebih percaya diri dalam menjalankan pekerjaan, karena ikatan emosional yang sudah mengikat antar karyawan.

Kedua; Peran strategi pengembangan sumber daya manusia yang diterapkan oleh perusahaan CV. Barokah Jaya Hikmah Sidoarjo dalam meningkatkan efektivitas kinerja karyawan. Peran strategi pendampingan yang diterapkan oleh perusahaan CV. Barokah Jaya Hikmah Sidoarjo dinilai sudah cukup maksimal dilihat dari. 1) Hasil kerja dan waktu, hasil kerja yang dilakukan oleh karyawan dinilai sudah memuaskan oleh perusahaan, karena pendapatan perusahaan mengalami peningkatan dalam penghasilan per bulannya, meskipun terkadang proses pengerjaan yang dilakukan sedikit mengalami kemolaran waktu, tetapi perusahaan merasa bukan sebuah masalah asalkan target yang di harapkan perusahaan tercapai. 2). Kepuasan kinerja karyawan CV. Barokah Jaya Hikmah Sidoarjo dikatakan efektif. Karena perusahaan menilai pekerjaan yang dilakukan oleh karyawannya dilakukan secara maksimal dan penuh tanggung jawab dalam pekerjaan. 
Berdasarkan kesimpulan yang telah dipaparkan dalam penelitian ini, maka dapat diajukan beberapa saran sebagai berikut untuk penelitian selanjutnya, Jika ingin melakukan penelitian yang sejenis, sebaiknya memilih objek yang berbeda untuk dijadikan objek penelitian, serta menggunakan teori-teori yang berbeda untuk digunakan sebagai pisau analisa.

\section{DAFTAR PUSTAKA}

Aruperes Dinny M., Dkk, (2018). Strategi Manajemen Sumber Manusia Dalam Rangka Peningkatan Kinerja Karyawan PT Indofood CBP Sukses Makmur Tbk Bitung. Jurnal EMBA, 6(4): 23.

Darmawan, I. (2006). Pembangunan Manusia Sebagai Sarana Pemberdayaan Masyarakat Miskin. Jurnal Economia, 2(1): 1-11.

Ebel, R.L. \& Frisbie, D.A. (1991). Essential Of Educational Measurement $\left(5^{\text {th }}\right.$ Edition). New Delhi: Prentice-Hall, Inc.

Irma Ernawati, Muhammad Darwis Dan Muh. Nasrullah (2017). Efektivitas Kinerja Pegawai Pada Kantor Kec. Pallangga Kab. Gowa. Jurnal Official, 3(1):14.

https://kemenperin.go.id/direktori-perusahaan? what $=$ Plastik\&prov $=32 \&$ hal $=4,25$ Maret $2020: 21.30 \mathrm{WIB}$.

https://www.pinterpandai.com/pengertian-pt-cv-firma-ud-bumn-kopersai-yayasan/

21 Maret $2020: 21.30$ WIB.

Moh. Nazir,(2005). Metode Penelitian. Bogor: Penerbit Ghalia Indonesia,63.

Mutia Windi Astuti, Eri Bukhari, (2018). Analisis Kinerja Pegawai PT Investama. Jurnal:Risset Manajemen Sains Indonesia, 9(1):25.

Nurul Khurotin, Tri Wulida Afrianty. (2018). Analisis Pelatihan dan Pengembangan Sumber Daya Manusia PT. Beon Intermedia Cabang Malang. Jurnal Administrasi Bisnis, 16(1): 196.

Nurlina T. Muhyiddin, Dkk, (2017). Metode Penelitian ekonomi Dan Sosial. Jakarta: Salemba Empat, 28.

Paulina,(2016). Efektivitas Kinerja Karyawan Pegawai Pada PT. PLN (Persero) Distribusi Jawa Timur Area Malang Rayon Dinoyo Untuk Mewujudkan Pelayanan Prima. Jurnal Ilmu Sosial Dan Ilmu Politik, 5(1): 59.

Qustolani, H. Asep (2017). Pengaruh Kepuasan Kerja, Keadilan Prosedural Dan Kompensasi Terhadap Kinerja Karyawan. Jurnal: Ilmu Manajemen \& Akuntansi, 4(2):81.

Sigit Setioko, (2018). Toropong Aspirasi Politik Islam. Jurnal Tapis, 14(2):19.

Sugiono, (2008). Penelitian Kuantitatif Dan Kualitatif Dan R\&D. Bandung: Alfabeta, 243. 
Suharismi Arikunto, (1996). Prosedur Penelitian Suatu Pendekatan Praktik. Yogyakarta: Rineka Cipta,129. 